\title{
Karakteristik dan Komposisi Asam Lemak pada Minyak Biji Kenaf dari Lima Varietas Karangploso (KR)( Hibiscus cannabinus L.)
}

Fatty Acid Composition and Characteristics of Kenaf (Hibiscus cannabinus L.) Seed Oil from Five Different Varieties of Karangploso (KR)

\section{Elda Nurnasari*, Nurindah}

Balai PenelitianTanaman Pemanis dan Serat, Jl. Raya Karangploso, Kotak Pos 199 Malang, 65152, Indonesia *Penulis korespondensi: Elda Nurnasari, E-mail: eldanurnasari@yahoo.com

Tanggal submisi: 15 Agustus 2018; Tanggal penerimaan: 20 Maret 2020

\begin{abstract}
ABSTRAK
Kadar minyak biji kenaf tergolong cukup tinggi namun pemanfaatannya masih belum banyak dilakukan. Tujuan dari penelitian ini adalah untuk mengetahui kandungan senyawa asam lemak dan karakteristik kimia minyak biji kenaf yang berasal dari lima varietas unggul. Lima varietas kenaf yang telah dirilis oleh Balittas yakni Karangploso (KR) 6, 9, 11, 12, dan 14 memiliki kadar minyak Antara 22,71-32,32\% dari $5 \mathrm{~g}$ biji kering kenaf. Mutu minyak biji kenaf ditentukan dari hasil pengujian beberapa parameter diantaranya angka asam, kadar asam lemak bebas, angka iodium, bilangan penyabunan, dan angka peroksida. Angka asam berkisar antara $2,21 \mathrm{mg} \mathrm{KOH} / \mathrm{g}$ sampai $3,28 \mathrm{mg} \mathrm{KOH} / \mathrm{g}$. Kadar asam lemak bebas minyak biji kenaf bervariasi mulai dari 1,10-1,64\% (v/v). Bilangan penyabunan berkisar antara 194,97-243,91 mg KOH/g. Angka iodium berkisar antara 54,72-71,44 g Iod/100 g dan angka peroksida berkisar antara 33,97 mek/kg sampai 56,23 mek/kg. Minyak biji kenaf banyak mengandung asam lemak esensial dan yang paling tinggi adalah asam oleat (44,73\% KR 9; 43,01\% KR 14), dan asam linoleat (42,19\% KR 12).
\end{abstract}

Kata kunci: Asam lemak; kenaf; asam oleat; minyak biji

\begin{abstract}
The Kenaf seed has narrow applications despite the relatively high oil content. This study therefore aims to identify the fatty acid content and chemical characteristics of kenaf seed oil derived from five superior varieties released by Balittas. These include Karangploso (KR) 6, 9, 11, 12, and 14, estimated to have oil content between the range $22.71-32 .-32 \%$. Furthermore, the quality is determined by testing several parameters, encompassing the acid number, free fatty acid level, iodine, saponification and peroxide number. The result show an acid rate range of $2.21 \mathrm{mg} \mathrm{KOH} / \mathrm{g}$ (KR 12) - $3.28 \mathrm{mg} \mathrm{KOH} / \mathrm{g}$ (KR 11) in kenaf seed oil. Meanwhile, the free fatty acids varied from $1.10-1.64 \%$, with saponification $(194.97-243.91 \mathrm{mg} \mathrm{KOH} / \mathrm{g})$ iodine rate $(54.72-71.44 \mathrm{~g} \mathrm{Iod} / 100 \mathrm{~g}$ ) and peroxide rate $(33.97 \mathrm{mec} / \mathrm{kg}$ (KR 14) - $56.23 \mathrm{mec} / \mathrm{kg}$ (KR 6)). The kenaf seed oil was concluded to contain numerous essential fatty acids, and oleic acid (44.73\% KR 9; 43.01\% KR 14), as well as linoleic acid (42.19\% KR 12) exhibited the highest amounts.
\end{abstract}

Keywords: Fatty acid; kenaf; oleic acid; oil seed

DOI: http://doi.org/10.22146/agritech.38125

ISSN 0216-0455 (Print), ISSN 2527-3825 (Online) 


\section{PENDAHULUAN}

Kenaf (Hibiscus cannabinusL.) pada umumnya dibudidayakan untuk diambil serat batangnya. Serat kenaf termasuk dalam kelompok serat batang, banyak digunakan sebagai bahan baku pembuatan pulp, karung, komposit polypropylene dalam industry polimer, material absorbent untuk industri, particle board, filler organic untuk plastic serta untuk insulasi (Hidayati, 2009). Tanaman ini banyak ditanam dinegara-negara berkembang meskipun asalnya dari Afrika. Kenaf dapat tumbuh pada berbagai jenis lingkungan mulai dari lahan bonorowo (lahan yang menjadi rawa ketika musim hujan) hinggalahan kering (Santoso, Jamil, \& Machfud, 2015). Selain diambil seratnya, bagian lain dari tanaman kenaf memiliki banyak manfaat. Daun kenaf banyak mengandung senyawa bioaktif seperti senyawa fenolik, turunan triterpen, fitosterol, memiliki aktivitas antioksidan, antihipertensi dan antiproliferatif (Pascoal, Quirantes-Piné, Fernando, Alexopoulou, Segura-Carretero, 2015). Biji kenaf selama ini kurang dimanfaatkan dan hanya digunakan untuk pakan ternak (Ng et al., 2013; Nyam et al., 2015). Biji kenaf mengandung senyawa potensial antara lain senyawa asam lemak seperti asam palmitat, asam linoleat dan asam oleat (Mohamed, Bhardwaj, Hamama, Webber, 1995). Senyawa asam lemak adalah senyawa yang berperan dalam komunikasi antar sel dan menjadi senyawa prekursor (penyusun) bagi senyawa-senyawa penting lainnya dalam tubuh (Diana, 2013). Kandungan senyawa asam lemak utama dalam minyak biji kenaf antara lain asam oleat $(29,2 \%)$ dan linoleat $(45,9 \%)$ (Yazan et al., 2011); Nyam et al., 2015).

Produksi biji kenaf mencapai 270-900 kg/ha sehingga secara teknis dan ekonomi layak untuk dikembangkan (Dempsey, 1975 ; Mohamed et al., 1995). Kadar minyak biji kenaf adalah 20,4\%, hamper sama dengan kadar minyak biji kapas dan kedelai (Nyam, Tan, Lai, Long, Che Man, 2009). Selain kandungan asam lemak dalam minyak biji kenaf juga terdapat senyawa fosfolipid antara lain sphingomielin, phosphatidyl inositol, phosphatidyl choline, $\mathrm{N}$-acyl phosphatidyl ethanolamine, phosphatidyl ethanolamine, phosphatidyl ethanolamine, phosphatidic acid, phosphatidyl glycerol dan cardiolipin ((TolibaveMukhamedova, KhS Akramov, 1975), (Tolibave Mukhamedova, KhS Akramov, 1976), (TolibaveMukhamedova, WS Akramov, 1977), (Tolibave, Mukhamedova, KhS Glushennkova, Tursunkhodzhaev, 1986) (Tolibave Mukhamedova, KhS Glushennkova, 1989),(Tolibave, Mukhamedova, WS Rakhimov, Glushennkova, 1990);(Mukhamedova, Tolibave, Glushennkova, 1988); Mohamed et al., 1995;Cheng, Haque Akanda, \& Nyam, 2016).
Kandungan senyawa potensial dalam minyak biji kenaf dapat digunakan untuk meningkatkan nilai tambah tanaman kenaf, khususnya untuk diversifikasi produk dan pemanfaatan hasil samping. Hasil penelitian menunjukkan bahwa minyak biji kenaf aman untuk dikonsumsi manusia karena mengandung asam lemak dan antioksidan (Chukwuma Omenna, Cynthia Uzuegbu, Deborah Okeleye, 2017). Minyak biji kenaf diekstrak dengan beberapa metode antara lain, metode fisik (screw press), ekstraksi pelarut, dan supercritical fluid extraction (SFE) (Cheng W. Y., Haque Akanda, J. M., \& Nyam, K. L.,2016). Minyak biji kenaf adalah minyak nabati yang komposisinya hamper sama dengan minyak biji kapas. Bergantung pada suhu pengolahan, minyak biji kenaf menghasilkan berwarna kuning kecoklatan sampai coklat kemerahan dengan bauringan (Cheng W. Y., Haque Akanda, J. M., \& Nyam, K. L., 2016).

Balittas telah merilis 13 varietas unggul kenaf yaitu Karangploso (KR) 1, 2, 3, 4, 5, 6, 9, 11, 12, 14, 15, dan Kenafindo 1 dan 2. Varietas KR 9 dan KR 12 sesuai ditanam pada lahan kering, KR 11 sesuai untuk lahan bonorowo, dan KR 14 dan KR 15 sesuai untuk lahan podsolik merah kuning (PMK). Varietas unggul kenaf ini memiliki produktivitas yang lebih tinggi yakni 2,75 4,20 ton/ha, varietas kenaf sebelumnya hanya memiliki produktivitas 0,9-1,2 ton/ha (Anonymous, 2019; Anonymous, 2014). Varietas unggul kenaf tersebut masih belum dianalisa kandungan asam lemak dalam minyak biji kenaf. Tujuan dari penelitian ini adalah untuk mengetahui profil senyawa asam lemak dan karakteristik kimia minyak biji kenaf pada 5 varietas kenaf yakni KR 6, KR 9, KR 11 KR 12 dan KR 14. Karakteristik kimia yang diamati antara lain kadar minyak, angka asam, bilangan penyabunan, angka iodium, dan angka peroksida. Data ini diharapkan dapat menjadi informasi penting dalam pemanfaatan minyak biji kenaf dalam bidang farmakologi dan kesehatan.

\section{METODE PENELITIAN}

\section{Bahan}

Biji kenaf yang digunakan berasal dari lima varietas unggul kenaf antara lain $K R$ 6, KR 9, KR 11 KR 12 dan KR 14. Biji kenaf diperoleh dari Kebun Percobaan Karangploso milik Balai Penelitian Tanaman Pemanis dan Serat di Kabupaten Malang. Bahan kimia yang digunakan antara lain petroleum eter (Merck), etanol (Merck, 95\%), NaOH (Merck, 0,1 N), n-heksana (Merck,99\%), alkohol (Merck, 96\%), KOH (Merck, 0,1 $\mathrm{N}), \mathrm{HCl}$ (Merck , 0,5 N), $\mathrm{CHCl}_{3}$ (Merck, 99\%), Larutan Hanus, $\mathrm{KI}$ (Merck, 15\%), $\mathrm{Na}_{2} \mathrm{~S}_{2} \mathrm{O}_{3}$ (Merck , 0,1 N), asam asetat glacial (Merck, 99\%), indikator pp, thymol blue, 
amilum. Semua bahan kimia yang digunakan dalam penelitian ini memiliki tingkat kemurnian yang tinggi (pa).

\section{Alat}

Penelitian ini menggunakan peralatan sebagai berikut blender, alat sokletasi, kolom titrasi, peralatan gelas laboratorium, dan alat GCMS (Shimadzu QP2010S, Jepang).

\section{Ekstraksi Minyak Biji Kenaf}

Minyak biji kenaf diperoleh dengan cara fisik yaitu di press dengan mesin pres ulir (screw press). Mesin pres ulir yang digunakan dalam penelitian ini menggunakan mesin pres yang berada di Balai Penelitian Tanaman Pemanis dan Serat (BALITTAS), Karangploso, Jawa Timur. Data kadar minyak biji kenaf diperoleh melalui ekstraksi sokletasi. Minyak yang diperoleh selanjutnya disimpan dalam botol kaca gelap tertutup rapat dan diletakkan dalam suhu ruang, ditempat yang tidak terkena sinar matahari secara langsung.

\section{Analisa Karakteristik Kimia Minyak Biji Kenaf}

Karakteristik kimia minyak biji kenaf antara lain kadar minyak, angka asam, asam lemak bebas, bilangan penyabunan, angka iodium dan angka peroksida.

\section{Kadar minyak}

Biji kenaf ditimbang sebanyak $50 \mathrm{~g}$, kemudian dioven pada suhu $65^{\circ} \mathrm{C}$ selama 2 jam. Biji kenaf lalu dihaluskan dengan cara diblender dan ditimbang sebanyak 5 gram. Sampel sebelum dimasukkan kelabu soxhleat, dibungkus terlebih dahulu dengan kertas saring. Pelarut petroleum eter $(250 \mathrm{~mL})$ dimasukkan kedalam labu soxhleat. Sokletasi dilakukan untuk memisahkan minyak dari pelarutnya. Ekstrak minyak lalu dipindahkan kedalam botol timbang yang sudah diketahui beratnya dan dipanaskan ke dalam oven dengan suhu $100^{\circ} \mathrm{C}$ selama 1 jam. Ekstrak minyak kemudian didinginkan dalam desikator selama 15 menit, kemudian ditimbang beratnya. Kadar minyak dihitung dengan Persamaan 1.

Kadar minyak $(\%)=\frac{B-C}{B-A} \times 100 \%$

Keterangan:

$\mathrm{A}=$ Berat kertas saring $(\mathrm{g})$

$\mathrm{B}=$ Berat sampel sebelum diekstrak $(\mathrm{g})$

$\mathrm{C}=$ Berat sampel setelah diekstrak $(\mathrm{g}-)$

\section{Angka Asam}

Minyak biji kenaf ditimbang sebanyak 2-5 g dan dimasukkan kedalam erlenmeyer $250 \mathrm{~mL}$, kemudian ditambahkan $50 \mathrm{~mL}$ etanol $95 \%$ netral dan 3-5 tetes indikator PP. Larutan lalu dititrasi dengan standar $\mathrm{NaOH}$ $0,100 \mathrm{~N}$ hingga terjadi perubahan warna menjadi merah muda (tidak berubah selama 15 detik). Angka asam dinyatakan sebagai $\mathrm{mg} \mathrm{KOH} / \mathrm{g}$ lemak, dihitung dengan menggunakan Persamaan 2 (Sudarmaji, Haryono, Suhardi, 1997).

Angka asam $=\frac{V x T x 56,1}{m}$

$\mathrm{V}=$ Volume $\mathrm{NaOH}$ yang diperlukan dalam titrasi $(\mathrm{mL})$

$\mathrm{T}=$ Normalitas $\mathrm{NaOH}$

$\mathrm{m}=$ Berat sampel dalam $\mathrm{g}$

\section{Asam Lemak Bebas}

Sampel minyak biji kenaf ditimbang sebanyak $3 \mathrm{~g}$, dimasukkan kedalam erlenmeyer yang telah ditimbang beratnya. Sampel ditambahkan n-heksana sebanyak $10 \mathrm{~mL}$ dan alkohol $96 \%$ sebanyak $20 \mathrm{~mL}$. Campuran lalu ditambahkan 3 tetesin dikatortimol biru (BTB)

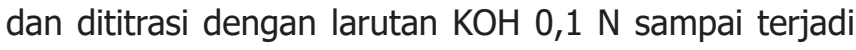
perubahan warna dari kuning menjadi kehijau-hijauan. Dilakukan perlakuan yang sama sebanyak dua kali. Kadar asam lemak bebas dihitung dengan menggunakan persamaan 3 (Sudarmaji et al., 1997).

Asam Lemak Bebas (\%)=

$\frac{m l K O H ~ 0,1 \text { NxNKOHxBM }}{\text { Keterangan: beratsampel }} \times 100 \%$

(Persamaan 3)

$\mathrm{N}=$ Normalitas $\mathrm{KOH}$ yang digunakan untuk titrasi $(\mathrm{N})$

$\mathrm{BM}=$ Berat molekul 25,6

\section{Bilangan Penyabunan}

Minyak biji kenaf ditimbang sebanyak $2 \mathrm{~g}$ dan dimasukkan kedalam labu dasar bulat $250 \mathrm{~mL}$ Larutan $\mathrm{KOH}$ alkohol 0,5 N ditambahkan sebanyak $25 \mathrm{~mL}$ dan dimasukkan beberapa butir batu didih. Labu dasar bulat kemudian dihubungkan dengan pendingin tegak diatas pemanas listrik selama 1 jam. Fenolftalein ditambahkan sebanyak 0,5 - $1 \mathrm{~mL}$ kedalam larutan tersebut dan dititrasi dengan $\mathrm{HCl} 0,5 \mathrm{~N}$ sampai warna indicator berubah menjadi tidak berwarna. Dilakukan perlakuan yang sama sebanyak dua kali. Bilangan penyabunan dinyatakan sebagai mg KOH per g lemak dan dihitung dengan menggunakan persamaan 4 (Sudarmaji et al., 1997)

Bilangan penyabunan $=\frac{m l K O H 0,1 N x N K O H x B M}{\text { beratsampel }} \times 100 \%$
Keterangan: 
Vo = Volume $\mathrm{HCl}$ 0,5 $\mathrm{N}$ yang diperlukan pada penitaran blanko $(\mathrm{mL})$

$\mathrm{V} 1$ = Volume $\mathrm{HCl}$ 0,5 $\mathrm{N}$ yang diperlukan pada penitaran contoh $(\mathrm{mL})$

$\mathrm{T}=$ Normalitas $\mathrm{HCl} \mathrm{0,5 \textrm {N }}$

$\mathrm{m}=$ Bobotcontohdalam gram

\section{Angka Iodium}

Angka iodium ditentukan dengan metode iodometri, minyak biji kenaf ditimbang sebanyak 0,1 $0,5 \mathrm{~g}$, kemudian ditambahkan $20 \mathrm{~mL} \mathrm{CHCl}_{3}$ dan larutan hanus lalu ditutup dan dibiarkan di tempat gelap selama 30 menit dengan sekali-kali dikocok. Larutan KI 15\% ditambahkansebanyak $20 \mathrm{~mL}$ dan $100 \mathrm{~mL}$ aquades kemudian Erlenmeyer ditutup dan dikocok dengan hatihati. Larutan kemudian dititrasi dengan larutan tiosulfat 0,1 N sampai warna larutan berubah menjadi kuning pucat/muda. Setelah larutan berwarna kuning pucat ditambahkan $2 \mathrm{~mL}$ indicator amilum. Titrasi dilanjutkan sampai warna biru hilang.

Angka iodium dihitung menggunakan data banyaknya volume larutan tiosulfat $0,1 \mathrm{~N}$ yang dipakai untuk titrasi blanko (B) dan yang dipakai pada titrasi sampel (S). Titrasi blanko dilakukan dengan cara larutan $\mathrm{CHCl}_{3}(20 \mathrm{~mL})$ dan larutan hanus $(25 \mathrm{~mL})$ dicampur kemudian ditutup dan dibiarkan ditempat gelap selama 30 menit dengan sekali-kali dikocok. Setelah itu ditambahkan $20 \mathrm{~mL}$ larutan KI 15\% dan $100 \mathrm{~mL}$ aquades kemudian Erlenmeyer ditutup dan dikocok dengan hati-hati. Larutan kemudian dititrasi dengan larutan tiosulfat $0,1 \mathrm{~N}$ sampai warna larutan berubah menjadi kuning pucat. Setelah larutan berwarna kuning pucat ditambahkan $2 \mathrm{~mL}$ indicator amilum. Titrasi dihentikan pada saat warna biru hilang. Angka iodium dinyatakan dalam $\mathrm{g}$ iod/100 $\mathrm{g}$ dan dihitung dengan menggunakan rumus di bawah ini (Sudarmaji et al., 1997)

Angka iodium $=\frac{56,1 \times T x(V o-V 1)}{m}$

Keterangan :

$\mathrm{B}=$ Banyaknya $\mathrm{Na}_{2} \mathrm{~S}_{2} \mathrm{O}_{3} 0,1 \mathrm{~N}$ yang dipakai pada titrasi blanko

$\mathrm{S}=$ Banyaknya $\mathrm{Na}_{2} \mathrm{~S}_{2} \mathrm{O}_{3} 0,1 \mathrm{~N}$ yang dipakai pada titrasi sampel

$\mathrm{N}=$ Normalitas larutan $\mathrm{Na}_{2} \mathrm{~S}_{2} \mathrm{O}_{3} 0,1 \mathrm{~N}$ setelah distandarisasi

$\mathrm{G}=$ Bobot sampel

$12,69=$ Bobot atom iodium

10

\section{Bilangan Peroksida}

Minyak biji kenaf ditimbang sebanyak 0,3-5,0 $\mathrm{g}$ dan dimasukkan kedalam erlenmeyer. Campuran larutan $20 \mathrm{~mL}$ asam asetat glasial dan $25 \mathrm{~mL}$ etanol 95\% dan $55 \mathrm{~mL}$ kloroform ditambahkan kedalam sampel minyak biji. Kristal KI ditambahkan sebanyak 1 g kemudian campuran disimpan ditempat gelap selama 30 menit. Air suling bebas $\mathrm{CO}_{2}$ ditambahkan sebanyak $50 \mathrm{~mL}$. Larutan dititrasi dengan larutan standar natrium tiosulfat 0,02 $\mathrm{N}$ dengan larutan kanji sebagai indikator. Bilangan peroksida dihitung dengan persamaan di bawah ini (Sudarmaji et al., 1997).

$$
\text { Bilangan peroksida }(\mathrm{mek} / \mathrm{kg})=\frac{(V 1-V 0) \times T}{m} \times 1000
$$

Keterangan:

$\mathrm{V} 0=$ Volume daril arutan natrium tiosulfat untuk blanko, dalam $\mathrm{mL}$

V1 = Volume $(\mathrm{mL})$ larutan natrium tiosulfat untuk contoh

$\mathrm{T}=$ Normalitas larutan standar natrium tiosulfat yang digunakan

$\mathrm{m}=$ Berat contoh dalam gram

\section{Analisa profil senyawa asam lemak minyak biji kenaf}

Analisis senyawa asam lemak dalam minyak biji kenaf dilakukan menggunakan metoda GC-MS (Shimadzu QP-2010S, Japan). Sampel minyak biji kenaf sebelum diinjeksikan ke alat GC-MS dilakukan preparasi sampel dengan metode transesterifikasi. Sampel minyak ditambahkan larutan $\mathrm{BF}_{3}$ :methanol dengan perbandingan 1:3, divortek, kemudian di panaskan pada suhu $60^{\circ} \mathrm{C}$ selama 60 menit. Sampel kemudian ditambahkan $\mathrm{n}$-heksana $1 \mathrm{~mL}$, divortex, didiamkan selama beberapa menit dan akan terbentuk 2 lapisan, lapisan atas diambil sebanyak $1 \mu \mathrm{L}$ untuk dianalisis pada alat kromatografi gas.

Kolom yang digunakan adalah Agilent HP 5MS ( $p=30 \mathrm{~m}, \Phi=0,25 \mathrm{~mm}$ ). Gas pembawa adalah helium dengan kecepatan aliran $79,3 \mathrm{~mL} /$ menit serta tekanan kolom sebesar $13,0 \mathrm{kPa}$. Suhu kolom deprogram dari $50^{\circ} \mathrm{C}$ sampai $280^{\circ} \mathrm{C}$. Pada tahap awal suhu kolom deprogram konstan pada $50^{\circ} \mathrm{C}$ selama 5 menit, lalu dinaikkan menjadi $280^{\circ} \mathrm{C}$ dengan kecepatan kenaikan $5^{\circ} \mathrm{C} /$ menit.

Identifikasi senyawa dilakukan dengan membandingkan spectrum massa senyawa dengan data spectrum massa senyawa autentik dari NIST (National Institute Standard of Technology).

\section{HASIL DAN PEMBAHASAN}

\section{Karakteristik kimia minyak biji kenaf}

Karakteristik kimia yang penting dari minyak biji antara lain kadar minyak, angka asam, angka lemak bebas, bilangan penyabunan, angka iodium, dan angka peroksida. Sifat-sifat kimia minyak berhubungan dengan proses penanganan minyak lebih lanjut. Sifatsifat tersebut menggambarkan kualitas minyak dan 
kemungkinan penggunaannya sebagai bahan baku proses pembuatan produk tertentu. Karakteristik kimia minyak biji kenaf dari 5 jenis varietas disajikan dalam Tabel 1 . Kadar minyak tertinggi minyak biji kenaf adalah pada varietas KR 11 yakni 32,32\% dan yang paling kecil pada varietas KR 6 sebesar 22,71\%. Lima varietas unggul memiliki kadar minyak yang jauh lebih tinggi daripada kadar minyak biji kenaf yang berasal dari luar negeri diantaranya varietas Tainung, Everglades yang rata-rata kadar minyaknya sebesar 19,84\% (Coetzee, Labuschagne, Hugo, 2008), varietas Cuba (14.8\%) dan Dowling (12.7\%) (Igbo, U.E, Osinubi, M. A., Ishola, R. O., Isiba, V. I., Akubueze, E. U., Aroke, A. S., Elemo., 2016). Perbedaan kadar minyak biji ditentukan oleh banyak factor diantaranya adalah jenis varietas, lingkungan tempat tumbuh (sifat tanah, iklim, kelembaban, dII), metode ekstraksi, tahap pematangan dan waktu panen biji (Igbo U.E, Osinubi, M. A., Ishola, R. O., Isiba, V. I., Akubueze, E. U., Aroke, A. S., Elemo., 2016). Minyak biji kenaf merupakan minyak yang aman untuk dikonsumsi (edible oil) dan memiliki komposisi hamper sama dengan minyak biji kapas (Cheng W. Y., Haque Akanda, J. M., \& Nyam, K. L., 2016). Kadar minyak yang cukup tinggi dan termasuk minyak nabati yang aman dikonsumsi (edible vegetable oil) maka minyak biji kenaf berpotensi untuk dimanfaatkan sebagai bahan baku di industri kimia, biodiesel, sabun, surfaktan dan deterjen (Gadwal \& Naik, 2015). Angka asam merupakan sifat kimia minyak yang menyatakan ukuran tingkat kerusakan lemak atau minyak akibat proses hidrolisis (Mursalin, 2014). Angka asam terbesar adalah pada varietas KR 11 sebesar 3,28 $\mathrm{mg} \mathrm{KOH} / \mathrm{g}$ dan yang paling rendah pada varietas $\mathrm{KR}$ 12 sebesar $2,21 \mathrm{mg} \mathrm{KOH} / \mathrm{g}$. Hasil tersebut lebih rendah apabila dibandingkan dengan varietas Cuba $(3.80 \mathrm{mg}$ $\mathrm{KOH} / \mathrm{g}$ ) dan Dowling (5.50 mg $\mathrm{KOH} / \mathrm{g}$ ). Angka asam merupakan salah satu indicator pengukuran kualitas minyak (Igbo, U.E, Osinubi, M. A., Ishola, R. O., Isiba, V. I., Akubueze, E. U., Aroke, A. S., Elemo., 2016), semakin tinggi angka asam yang terkandung dalam minyak, maka tingkat kerusakan minyak juga semakin tinggi (Ketaren, 1986). Faktor-faktor yang mempengaruhi besarnya angka asam antara lain kondisi bahan baku, tingkat kemurnian minyak dan cara penyimpanan yang dapat menyebabkan terjadinya hidrolisis (Mittelbach and Remschmidt, 2006; Handayani et al., 2015).

Parameter lain yang menentukan kualitas minyak adalah kadar asam lemak bebas. Asam lemak bebas adalah asam lemak yang tidak terikat sebagai trigliserida. Kadar asam lemak bebas pada minyak biji kenaf bervariasi mulai dari 1,10-1,64 \%. Kandungan asam lemak bebas yang tinggi akan berpengaruh terhadap kualitas produk. Asam lemak bebas berpengaruh terhadap rasa, bau dan kualitas minyak, semakin tinggi kadar asam lemak bebas maka semakin rendah kualitas minyak (Nurhasnawati, Supriningrum, Akademi, Samarinda, 2015). Asam lemak bebas pada varietas KR tergolong rendah bila dibandingkan dengan hasil penelitian (Igbo, U.E, Osinubi, M. A., Ishola, R. O., Isiba, V. I., Akubueze, E. U., Aroke, A. S., Elemo., 2016) yakni untuk varietas Cuba (1,9\%) dan Dowling (2,7\%), kedua varietas ini berasal dari Nigeria.

Faktor penentu kualitas minyak yang ketiga adalah bilangan penyabunan atau bilangan saponifikasi. Bilangan penyabunan minyak biji kenaf yang berasal dari lima varietas berkisar antara 194,97 - 243,91 mg $\mathrm{KOH} / \mathrm{g}$. Paling rendah adalah pada varietas KR 12 dan tertinggi pada varietas KR 6 . Berat molekul minyak sangat mempengaruhi besarnya nilai dari bilangan penyabunan. Minyak dengan berat molekul rendah berarti mengandung asam lemak dengan rantai pendek, begitu pula sebaliknya. Faktor lain yang mempengaruhi nilai bilangan penyabunan adalah factor lingkungan, misalnya tempat tumbuh, iklim, waktu panen, dan musim. Faktor genetik dan proses ekstraksi minyak juga dapat berpengaruh terhadap bilangan penyabunan (Handayani et al., 2015).

Parameter penentu kualitas minyak yang keempat adalah angka iodium. Angka iodium menyatakan jumlah (gram) iod yang dapat diserap oleh 100 gram minyak. Angka iodium menyatakan derajat ketidakjenuhan minyak, semakin besar angka iodium maka derajat ketidakjenuhan semakin tinggi (banyak mengandung ikatan rangkap). Angka iodium lebih dari $46 \mathrm{~g}$ Iod/100 $\mathrm{g}$ mengindikasikan bahwa minyak tersebut memiliki tingkat ketidakjenuhan tinggi sehingga minyak mudah teroksidasi. Semakin tinggi angka iodium suatu minyak maka semakin baik mutunya dan aman untuk dikonsumsi (Nugraheni, 2011). Angka iodium minyak biji kenaf berkisar antara 54,72 - 71,44 g Iod/100 g, sehingga minyak kenaf merupakan salah satu jenis minyak yang dapat dikonsumsi. Menurut Ratnawati and Sungkawa (2017) minyak yang baik mengandung asam lemak tak jenuh lebih banyak dibandingkan dengan asam lemak jenuhnya.

Angka peroksida minyak biji kenaf berkisar antara 33,97 mek/kg (KR 14) sampai 56,23 mek/kg (KR 6). Proses oksidasi dan polimerisasi dalam minyak menyebabkan adanya kandungan peroksida didalam minyak, kandungan peroksida tersebut diukur sebagai angka peroksida (Sudarmaji et al., 1997). Angka peroksida pada minyak biji kenaf varietas KR termasuk tinggi bila dibandingkan dengan minyak biji kenaf varietas lain, menurut (Gadwal \& Naik, 2015) angka peroksida minyak biji kenaf dari India sebesar 13,3 mek/ $\mathrm{kg}$ dan dari varietas Cuba (5 mek/kg) dan Dowling (13 $\mathrm{mek} / \mathrm{kg}$ ) yang berasal dari Nigeria (Igbo, U.E, Osinubi, 
Tabel 1. Komposisi kimia minyak biji kenaf

\begin{tabular}{llllll}
\hline \multirow{2}{*}{ Komposisikimia } & \multicolumn{4}{c}{ Varietas Kenaf } \\
\cline { 2 - 5 } Kadar minyak (\%) & KR 6 & KR 9 & KR 11 & KR 12 & KR 14 \\
Angka asam (mg KOH/g) & $22,71 \pm 0,37$ & $24,45 \pm 1,05$ & $32,32 \pm 4,45$ & $28,16 \pm 5,44$ & $24,02 \pm 0,26$ \\
Asam lemak bebas (\%) & $3,00 \pm 0,00$ & $2,89 \pm 0,01$ & $3,28 \pm 0,02$ & $2,21 \pm 0,01$ & $2,37 \pm 0,03$ \\
Bilangan penyabunan (mg KOH/g) & $1,50 \pm 0,00$ & $1,44 \pm 0,01$ & $1,64 \pm 0,01$ & $1,10 \pm 0,01$ & $1,18 \pm 0,01$ \\
Angka iodium (g Iod/100 g) & $243,91 \pm 0,28$ & $195,23 \pm 0,86$ & $209,11 \pm 0,02$ & $194,97 \pm 0,02$ & $221,73 \pm 0,62$ \\
Angka peroksida (mek/kg) & $71,44 \pm 0,16$ & $69,19 \pm 0,07$ & $54,72 \pm 0,07$ & $57,71 \pm 0,13$ & $69,58 \pm 0,09$ \\
\hline
\end{tabular}

M. A., Ishola, R. O., Isiba, V. I., Akubueze, E. U., Aroke, A. S., Elemo, 2016). Hal ini berarti minyak biji kenaf pada penelitian ini sudah mengalami ketengikan karena nilai angka peroksida sudah diatas $30 \mathrm{mek} / \mathrm{kg}$. Aroma tengik pada minyak muncul Ketika minyak terlalu lama disimpan. Jadi minyak biji kenaf termasuk minyak yang memiliki umur simpan yang relatif rendah. Menurut ( $\mathrm{Ng}$ et al., 2013) minyak biji kenaf memiliki kandungan asam lemak tidak jenuh yang cukup tinggi (asam oleat : 43,01\%) sehingga apabila dilihat secara struktur kimia termasuk tidak stabil dan rentan terhadap oksidasi lipid terutama saat terpapar oksigen, kelembaban, cahaya dan suhu tinggi. Pada penelitian ini tidak dilakukan pengaruh masa simpan minyak biji kenaf. Berdasarkan hasil ini maka diperlukan perlakuan pendahuluan (pretreatment) sebelum dilakukan ekstraksi minyak biji kenaf untuk mengurangi oksidasi lipid yang dapat menyebabkan kerusakan minyak. Berdasarkan hasil penelitian (Nyam et al., 2015) minyak biji kenaf yang dipretreatment dengan microwave memiliki angka peroksida yang lebih rendah $\left(8,97\right.$ meq $\left.\mathrm{O}_{2} / \mathrm{kg}\right)$ apabila dibandingkan dengan biji kenaf tanpa pretreatment $\left(9,83\right.$ meq $\left.\mathrm{O}_{2} / \mathrm{kg}\right)$.

Salah satu metode untuk memperpanjang masa simpan minyak biji kenaf adalah dengan mikro enkapsulasi. Metode mikro enkapsulasi dengan teknik co-ekstrusi(Co-extrusion technology) telah terbukti mampu melindungi minyak biji kenaf terhadap oksidasi lipid dan menunda degradasi antioksidan alami yang ada dalam minyak selama penyimpanan(Leong, Tan, \& Nyam, 2016).

\section{Profilsenyawaasam lemak minyakbiji kenaf}

Minyak biji kenaf mengandung senyawa asam lemak dengan komposisi yang bervariasi (Tabel 2). Data tersebut diperoleh dari kromatogram GC-MS (Gambar 1-5). Perbedaan jenis dan kadar asam lemak minyak biji kenaf dapat dipengaruhi oleh lingkungan tempat tumbuh, cuaca dan varietas tanaman. Dari kelima jenis varietas kenaf yang digunakan dalam penelitian ini semuanya mengandung asam palmitat $\left(\mathrm{C}_{16: 0}\right.$ ) dengan kadar 22,14-26,65\%. Kadar asam palmitat tertinggi adalah pada varietas KR 12 dan terendah pada varietas KR 14. Hal ini berarti kadar asam palmitat dalam minyak biji kenaf lebih tinggi daripada minyak biji kedelai, gandum, kesumba (safflower), wijen, bunga matahari, rapa (rape seed), dan hamper sama dengan minyak biji kapas dan zaitun (Harwood \& Gunstone, 2007). Asam palmitat termasuk jenis asam lemak jenuh (Saturated Fatty Acid) adalah asam lemak yang tidak memiliki ikatan rangkap pada atom karbon. Tanpa adanya ikatan rangkap menunjukkan bahwa asam lemak jenuh tidak peka terhadap oksidasi dan pembentukan radikal bebas seperti halnya asam lemak tidak jenuh (mengandung ikatan rangkap)(Sartika, 2008).

Selain mengandung asam palmitat, minyak biji kenaf juga mengandung asam stearate $\left(\mathrm{C}_{18}\right)$ kecuali untuk varietas $K R 12$. Kadar asam stearate berkisar antara 3,64-6,04\%. Kadar asam stearate tertinggi ada

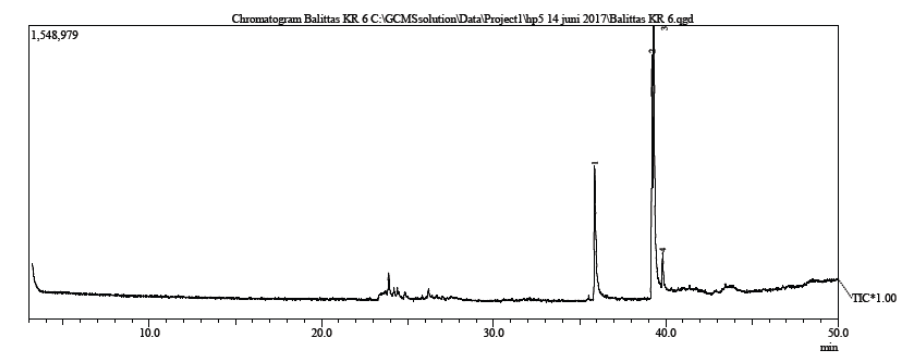

Gambar 1. Kromatogram GC-MS minyak biji kenaf varietas KR 6

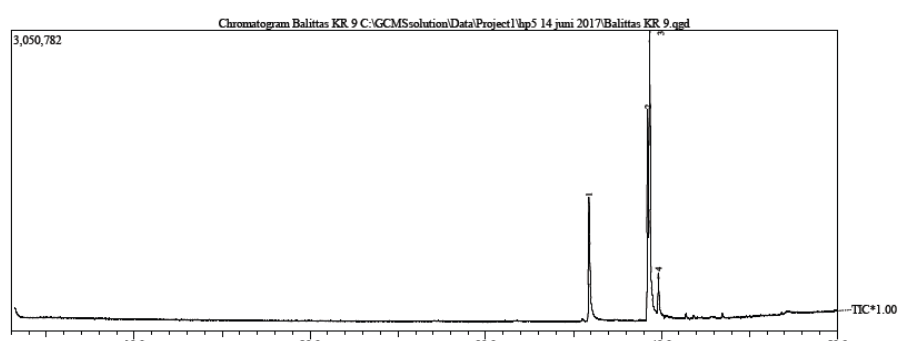

Gambar 2. Kromatogram GC-MS minyak biji kenaf varietas KR 9 


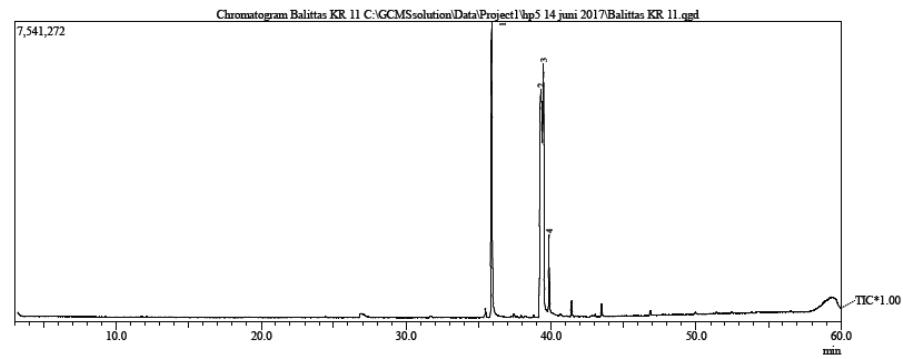

Gambar 3. Kromatogram GC-MS minyak biji kenaf varietas KR 11

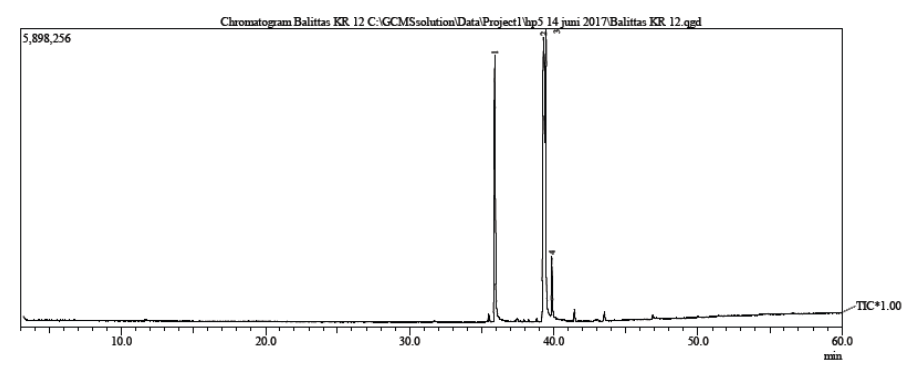

Gambar 4. Kromatogram GC-MS minyak biji kenaf varietas KR 12

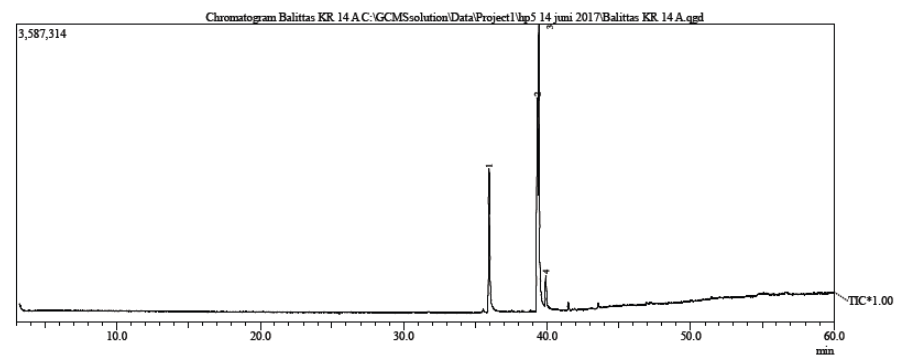

Gambar 5. Kromatogram GC-MS minyak biji kenaf varietas KR 14

pada varietas KR 9 dan terendah pada varietas KR 6 . Kadar asam stearate minyak biji kenaf masih lebih tinggi dari minyak kelapa $(2,00 \%)$, kacang tanah $(3,10 \%)$, kedelai $(3,20 \%)$, dan jagung $(2,20 \%)$ (Tuminah, 2009). Asam stearate adalah asam lemak netral karena termasuk jenis asam lemak jenuh namun tidak menyebabkan kenaikan kadar LDL kolesterol dalam darah (Coetzee et al., 2008).

Senyawa asam lemak dari kelompok asam lemak tak jenuh (Unsaturated Fatty Acid) dalam minyak biji kenaf yang berasal dari lima jenis varietas antara lain asam oleat, asam linoleat dan asam elaidat. Asam oleat terdapat dalam varietas KR 9, KR 12 dan KR 14 dengan kandungan tertinggi sebesar 44,73\% (KR 9). Kadar asam oleat minyak biji kenaf masih lebih tinggi dari minyak kelapa $(6,00 \%)$, kedelai $(22,30 \%)$, dan minyak bunga matahari $(18,60 \%)$, dan lebih rendah dari minyak kacang tanah $(53,80 \%)$ (Tuminah, 2009). Minyak nabati banyak mengandung asam oleat atau asam cis-9oktadekanoat. Kandungan terbesar asam oleat adalah pada minyak zaitun (55-80\%) dan pada minyak kelapa sawit mencapai $30-45 \%$. Peran asam oleat dalam bidang Kesehatan adalah untuk menjaga Kesehatan kulit. Selain itu, dengan satu ikatan rangkap, asam oleat bersifat netral terhadap LDL(low density lipoprotein) (tidak menurunkan atau menaikkan), tetapi dapat meningkatkan lipoprotein HDL (high density lipoprotein) (Mora \& Nandhana Selpas, 2013). Kandungan asam oleat yang tinggi berpengaruh pada stabilitas panas yang lebih baik selama proses pemasakan apabila digunakan sebagai minyak makan(Igbo, U.E, Osinubi, M. A., Ishola, R. O., Isiba, V. I., Akubueze, E. U., Aroke, A. S., Elemo, 2016).

Minyak biji kenaf juga mengandung asam linoleat yang cukup tinggi $(39,72-42,19 \%)$ bila dibandingkan dengan minyak nabati yang lain seperti minyak kelapa $(0,10 \%)$, minyak bunga matahari $(0,10 \%)$ (Tuminah, 2009), minyak kelapa sawit (7-11\%) (Mora \& Nandhana Selpas, 2013). Hasil yang sama juga dilaporkan oleh (Coetzee et al., 2008) bahwa kadar asam linoleate minyak biji kenaf pada 8 varietas di Afrika Selatan adalah antara $28,60-49,75 \%$. Asam linoleate adalah asam lemak essensial yang dalam metabolism tubuh berubah menjadi asam eicosapentaenoat (EPA) sebagai precursor eicosanoid yang memiliki aktivitas anti-inflamasi (peradangan) dan anti-trombotik (Ruiz, Castillo, Dobson, Brennan, Gordon, 2002);(Coetzee et al., 2008).

Komposisi asam lemak yang terdapat dalam minyak

Tabel 2. Komposisi senyawa asam lemak minyak biji kenaf

\begin{tabular}{lccccc}
\hline \multirow{2}{*}{ Asam Lemak } & \multicolumn{5}{c}{ Varietas Kenaf } \\
\cline { 2 - 5 } & KR 6 & KR 9 & KR 11 & KR 12 & KR 14 \\
\hline 1. Jenuh (Saturated) & 23,33 & 23,10 & 26,61 & 26,65 & 22,14 \\
Asam Palmitat $\left(\mathrm{C}_{16}\right)(\%)$ & 3,64 & 6,04 & 4,84 & - & 4,13 \\
Asam Stearat $\left(\mathrm{C}_{18}\right)(\%)$ & - & 44,73 & - & 25,40 & 43,01 \\
\hline 2. Tak Jenuh $($ Unsaturated) & - & - & 39,72 & 42,19 & - \\
Asam Oleat $\left(\right.$ Cis $\left.\mathrm{C}_{18: 1} ; \omega_{9}\right)(\%)$ & - & - & 28,83 & 5,75 & - \\
Asam Linoleat $\left(\mathrm{C}_{18: 2} ; \omega_{6}\right)(\%)$ & & & & & \\
Asam Elaidat $\left(\mathrm{C}_{18}\right)(\%)$ & &
\end{tabular}


biji kenaf memiliki jenis dan jumlah yang bervariasi, hal ini dikarenakan perbedaan varietas, lingkungan tempat tumbuh dan lain-lain. Hal ini sesuai dengan pernyataan (Dhar, Kar, Ojha, Pandey, Mitra, 2015) bahwa terdapat variasi kadar minyak biji kenaf, profil senyawa asam lemak, komposisi senyawa bioaktif essensial dan komponen fitokimia yang diperoleh dari lokasi yang berbeda secara geografis. Minyak biji kenaf varietas Tainung memiliki kandungan asam linoleate sebesar 47.30 \% (Cheng W. Y., Haque Akanda, J. M., \& Nyam, K. L., 2016) sedangkan pada varietas KR 11 sebesar 39,72 $\%$ dan KR 12 sebesar 42,19\%. Asam linoleate memiliki peran dalam pertumbuhan, pemeliharaan membrane sel, pengaturan metabolism kolesterol, menurunkan tekanan darah, menghambat lipogenesis hepatik, transport lipid, precursor dalam sintesis prostagladin, membentuk arakhidonat dalam proses reproduksi (Iskandar, 2004).

\section{KESIMPULAN}

Biji kenaf yang merupakan produk samping tanaman kenaf mengandung minyak dengan kadar minyak cukup tinggi dan kandungan asam lemak essential. Kadar minyak biji kenaf dari lima varietas KR 6, 9, 11, 12 dan 14 berkisar antara 22,71-32.32 \%. Minyak biji kenaf mengandung asam lemak tak jenuh (asam oleat, asam linoleat, dan asam elaidat) dan asam lemak jenuh (asam palmitat dan asam stearat). Kandungan asam lemak essential yang cukup tinggi menjadikan minyak biji kenaf termasuk dalam minyak yang aman dikonsumsi (edible oil) serta bermanfaat bagi kesehatan. Tanaman kenaf memiliki potensi yang tinggi untuk dikembangkan selain sebagai tanaman penghasil serat batang.

\section{UCAPAN TERIMA KASIH}

Penulis mengucapkan terimakasih kepada Kepala Balai Penelitian Tanaman Pemanis dan Serat atas kesempatan untuk melaksanakan penelitian ini. Penelitian ini dibiayai dari dana insentif PUI Tanaman Serat.

\section{KONFLIK KEPENTINGAN}

Penulis menyatakan bahwa artikel ini asli hasil penelitian para penulis, tidak ada konflik kepentingan dan hanya dipublikasikan pada jurnal ini.

\section{DAFTAR PUSTAKA}

Anonymous. (2014). Mengenal tanaman kenaf dan prospeknya. Retrieved from https://www.pedekik.com/ mengenal-tanaman-kenaf-dan-prospeknya/

Anonymous. (2019). Kenaf. Retrieved from http://balittas. litbang.pertanian.go.id/index.php/produk/varietasunggul/kenaf

Cheng, W. Y., Haque Akanda, J. M., \& Nyam, K. L. (2016). Kenaf seed oil: A potential new source of edible oil. Trends in Food Science and Technology, 52, 57-65. https://doi.org/10.1016/j.tifs.2016.03.014

Chukwuma Omenna, E., Cynthia Uzuegbu, D., Deborah Okeleye, D., \& Author, C. (2017). Functional and Nutritional Properties of Kenaf Seed. EC Nutrition, 11, 166-172. Retrieved from https://www.ecronicon.com/ ecnu/pdf/ECNU-11-00384.pdf

Coetzee, R., Labuschagne, M., \& Hugo, A. (2008). Fatty acid and oil variation in seed from kenaf (Hibiscus cannabinus L.). Industrial Crops and Products, 27(1), 104-109. https://doi.org/10.1016/j.indcrop.2007.08.005

Dempsey, J. (1975). Fiber Crops. Gainesville, Florida: University of Florida Press,.

Dhar, P., Kar, C. S., Ojha, D., Pandey, S. K., \& Mitra, J. (2015). Chemistry, phytotechnology, pharmacology and nutraceutical functions of kenaf (Hibiscus cannabinus L.) and roselle (Hibiscus sabdariffa L.) seed oil: An overview. Industrial Crops and Products, 77, 323-332. https://doi. org/10.1016/j.indcrop.2015.08.064

Diana, F. M. (2013). Omega 6. Jurnal Kesehatan Masyarakat, Vol 7(1), Hal 26-31.

Gadwal, R., \& Naik, G. (2015). Studies on physicochemical properties and fatty acid profile of seed oil from two Hibiscus spesies. World Journal of Pharmaceutical Research, 4(2), 1573-1583.

Handayani, R., Rukminita, S., \& Gumilar, I. (2015). Karakteristik Fisiko-Kimia Minyak Biji Bintaro ( Cerbera manghas L ) dan Potensinya sebagai Bahan Baku Pembuatan Biodiesel. Jurnal Akuatika, 6(2), 177-186.

Harwood, J., \& Gunstone, F. (2007). Occurrence and Characterisation of Oils and Fats. In The Lipid Handbook (third edit, p. 20). London: Chapman and Hall.

Hidayati, Y. (2009). Hormon Auksin Pada Tanaman Kenaf. J. Agrovigor, 2(2), 89-96. Retrieved from http://pertanian. trunojoyo.ac.id/wp-content/uploads/2013/02/5. Agrovigor-Sept-2009-Vol-2-No-2-Kadar-Hormon-AuxinYunin- $\mathrm{H}$-.pdfcheng

Igbo, U. E., Osinubi, M. A., Ishola, R. O., Isiba, V. I., Akubueze, E. U., Aroke, A. S., Elemo, G. N. (2016). Effect of Varietal Difference on the Physicochemical Properties and Fatty Acid Profile of Kenaf Seed Oil. Scholarly Research Journal for Interdisciplinary Studies, (4), 2908-2913. Retrieved from www.srjis.com 
Iskandar, J. (2004). Menuju Hidup Sehat dan Awet Muda melalui Pencegahan dan Pengobatan. Jakarta: Buana Ilmu Populer.

Ketaren, S. (1986). Minyak dan Lemak Pangan, (Edisi I). Penerbit Universitas Indonesia (UI Press).

Leong, M., Tan, C., \& Nyam, K. (2016). Effects of Accelerated Storage on the Quality of Kenaf Seed Oil in ChitosanCoated High Methoxyl Pectin-Alginate Microcapsules. Journal of Food Science, 81(10), 2367-2372.

Mittelbach, M., \& Remschmidt, C. (2006). Biodiesel: The comprehensive handbook (3rd ed.). BoersedruckAustria: Boersedruck Ges.

Mohamed, A., Bhardwaj, H., Hamama, A., \& Webber, C. (1995). Chemical composition of kenaf (Hibiscus cannabinus L.) seed oil. Industrial Crops and Products, 4(3), 157-165. https://doi.org/10.1016/0926-6690(95)00027-A

Mora, E., \& Nandhana Selpas, dan. (2013). Isolasi dan Karakterisasi Asam Oleat dari Kulit Buah Kelapa Sawit (Elais guinensis Jacq.). Jurnal Penelitian Farmasi Indonesia, 1(2), 47-51.

Mukhamedova, K., Tolibave, I., \& Glushennkova, A. (1988). Purification of total phospho- and phosphonolipids from seeds of cotton and kenaf. Kim. Prir. Soedin, 6, 785-788.

Mursalin, et al. (2014). Karakterisasi sifat fisiko kimia minyak kelapa. In Prosiding Seminar dan Lokakarya Nasional FKPT-TPI. Universitas Riau (pp. 199-210).

Ng, S., Jessie, L., Tan, C., Long, K., \& Nyam, K. (2013). Effect of accelerated storage on microencapsulated kenaf seed oil. Journal of the American Oil Chemists' Society, 90(7), 1023-1029.

Nugraheni, D. T. (2011). Analisis Penurunan Bilangan Iod terhadap Pengulangan Penggorengan Minyak Kelapa dengan Metode Titrasi Iodometri, 3233. Retrieved from http://repository.uin-suska. ac.id/1337/1/2011_2011224.pdf

Nurhasnawati, H., Supriningrum, R., Akademi, N. C., \& Samarinda, F. (2015). Penetapan Kadar Asam Lemak Bebas Dan Bilangan Peroksida Pada Minyak Goreng Yang Digunakan Pedagang Gorengan Di Jl. a.W Sjahranie Samarinda. Jurnal Ilmiah Manuntung, 1(1), 25-30.

Nyam, K. L., Tan, C. H., \& Long, K. (2015). Effect of microwave pretreatment on stability of kenaf ( Hibiscus cannabinus L .) seed oil upon accelerated storage. International Food Research Journal, 22(5), 1898-1905.

Nyam, K. L., Tan, C. P., Lai, O. M., Long, K., \& Che Man, Y. B. (2009). Physicochemical properties and bioactive compounds of selected seed oils. LWT - Food Science and Technology, 42(8), 1396-1403. https://doi. org/10.1016/j.Iwt.2009.03.006

Pascoal, A., Quirantes-Piné, R., Fernando, A. L., Alexopoulou, E., \& Segura-Carretero, A. (2015). Phenolic composition and antioxidant activity of kenaf leaves. Industrial Crops and Products, 78, 116-123. https://doi.org/10.1016/j. indcrop.2015.10.028

Ratnawati, G., \& Sungkawa, H. (2017). Perbedaan Kadar Asam Lemak Bebas Pada Minyak Goreng Yang Mengalami Pemanasan Ulang Dengan Penambahan Bawang Merah (Allium cepa) DAN Bawang Putih (Allium sativum). Jurnal Laboratorium Khatulistiwa, 1(1), 89-83.

Ruiz, M. L., Castillo, D., Dobson, D., Brennan, R., \& Gordon, S. (2002). Genotypic variation in fatty acid content of blackcurrant seeds. J. Agric. Food Chem., 50, 332-335.

Santoso, B., Jamil, A. H., \& Machfud, M. (2015). Manfaat kenaf (Hibiscus cannabinus L .) dalam penyerapan karbondioksida (CO2). Perspektif, 14(2), 125-134. https://doi.org/10.21082/p.v14n2.2015.125-133

Sartika, R. A. D. (2008). Pengaruh asam lemak jenuh, tidak jenuh dan asam lemak trans terhadap kesehatan. Kesehatan Masyarakat Nasional, 2(4), 154-160. https:// doi.org/10.21109/kesmas.v2i4.258

Sudarmaji, S., Haryono, B., \& Suhardi. (1997). Analisa Bahan Makanan dan Pertanian. Yogyakarta: Liberty.

Tolibave, I., \& Mukhamedova, KhS Akramov, S. (1975). Phospholipids of kenaf. Kim. Prir. Soedin, 6, 799-800.

Tolibave, I., \& Mukhamedova, KhS Akramov, S. (1976). $\mathrm{N}$-Acylated phospholipids and lysophospholipids of kenaf seeds. Kim. Prir. Soedin, 6, 723-725.

Tolibave, I., \& Mukhamedova, KhS Glushennkova, A. (1989). PhosphonophosphatidyI ethanolamine from kenaf seeds. Kim. Prir. Soedin, 6, 848-849.

Tolibave, I., Mukhamedova, KhS Glushennkova, A., \& Tursunkhodzhaev, A. (1986). Lipids of kenaf wastes. Rim. Prir. Soedin, 6, 686-688.

Tolibave, I., \& Mukhamedova, WS Akramov, S. (1977). Phospholipids of seeds of kenaf of the variety "uzbekskii1503." Rim. Prir. Soedin, 6, 776-780.

Tolibave, I., Mukhamedova, WS Rakhimov, D., \& Glushennkova, A. (1990). Neutral lipids and polysaccharides of kenaf wastes. Kim. Prir. Soedin, 1, 25-27.

Tuminah, S. (2009). Efek Asam Lemak Jenuh dan Asam Lemak Tak Jenuh "Trans" Terhadap Kesehatan. Media Penelit. Dan Pengembang. Kesehat., XIX(Suplemen II), S13S20. https://doi.org/10.1007/s13398-014-0173-7.2

Yazan, L. S., Foo, J. B., Ghafar, S. A. A., Chan, K. W., Tahir, P. M., \& Ismail, M. (2011). Effect of kenaf seed oil from different ways of extraction towards ovarian cancer cells. Food and Bioproducts Processing, 89(4), 328-332. https://doi.org/10.1016/j.fbp.2010.10.007 